\title{
Maciej Bernatt, Administrative Sanctions: Between Efficiency and Procedural Fairness (Sankcje administracyjne: między efektywnością i proceduralną sprawiedliwością), "Review of European Administrative Law” 2016, vol. 9, iss. 1, s. 5-32, DOI: 10.7590/187479816X14628633832166.
}

Celem artykułu jest przedstawienie - z perspektywy Polski - wyzwania w budowaniu odpowiedniego systemu kar administracyjnych. Autor podkreśla, że sprawność funkcjonowania tego systemu powinna być zrównoważona. Wyważenia wymaga przestrzeganie sprawiedliwości proceduralnej, jak również efektywność odpowiedzialności administracyjnej, a zatem skuteczność w nakładaniu i egzekwowaniu sankcji.

Autor opracowania analizuje trzy obszary, w których potrzebne jest zrównoważone podejście do sankcji administracyjnych: pierwszy dotyczy podstaw odpowiedzialności administracyjnej, drugi zakresu praw proceduralnych, a trzeci instrumentów instytucjonalnych. W artykule określone zostały dwa czynniki, które powinny być brane pod uwagę przy stanowieniu i stosowaniu sankcji administracyjnych, tj. efektywność i sprawiedliwość proceduralna. Organy stanowiące i stosujące prawo powinny rozważać każdorazowo złożoności danej dziedziny prawa administracyjnego, a także surowości sankcji, tak aby kary były efektywne i sprawiedliwe.

W tekście analizie poddane zostały normy, które regulują postępowanie zmierzające do wymierzenia administracyjnych sankcji. Analiza uwzględniająca praktykę stosowania tych norm prowadzona była z punktu widzenia respektowania $\mathrm{w}$ tym postępowaniu sprawiedliwości proceduralnej. Sprawiedliwość proceduralna jest zasadą ogólną prawa, na którą składa się zbiór wartości, gwarantowanych przez sprawiedliwy przebieg postępowania. Przebieg procesu zgodny z tymi regułami sprawiedliwościowymi może się także przyczynić do osiągnięcia sprawiedliwego rezultatu i wymierzenia sprawiedliwej i efektywnej kary pełniącej funkcję prewencyjną. Na potrzeby analizy postępowania przed organem wyróżnione zostały wartości sprawiedliwości proceduralnej, które powinny być respektowane w postępowaniu przed organem posiadającym szerokie uprawnienia do ingerencji w sferę praw i wolności administrowanych poprzez nałożenie sankcji administracyjnych. Autor uznał, że wartościami tymi są: prawo do bycia wysłuchanym, prawo do obrony, prawo do poufności zarzutu i zaskarżalności rozstrzygnięcia. Poprawę w zakresie respektowania sprawiedliwości proceduralnej w postępowaniu zmierzającym do wymierzenia sankcji administracyjnej można osiągnąć w dużym stopniu poprzez dokonanie zmiany praktyki i wykładni obowiązującego prawa. Autor stwierdza w podsumowaniu, że treść obecnie obowiązujących przepisów daje możliwość wykładni, która będzie uwzględniać konieczność zagwarantowania poszczególnych wartości sprawiedliwości proceduralnej.

Lucyna Staniszewska

DOI: $10.14746 /$ spp.2017.2.18.11 